\title{
Propriedades de Compósitos Híbridos de Borracha Nitrílica, Fibras de Sisal e Carbonato de Cálcio
}

\author{
Marco A. lozzi \\ EESC - IFSC - IQSC, USP, São Carlos, 3M do Brasil \\ Maria A. Martins, Luiz H. C. Mattoso \\ Embrapa Instrumentação Agropecuária, São Carlos
}

Resumo: Neste trabalho, estudou-se a influência do teor de carbonato de cálcio nas propriedades mecânicas e térmicas da borracha nitrílica, e do comprimento das fibras de sisal nas propriedades mecânicas dos compósitos de borracha nitrílica/ fibras de sisal, e borracha nitrílica/carbonato de cálcio/fibras de sisal. Os materiais foram caracterizados através de ensaios mecânicos de resistência à tração, microscopia eletrônica de varredura (MEV), e termogravimetria (TG). O melhor desempenho mecânico dos compósitos com as fibras curtas aleatoriamente distribuídas foi obtido para o comprimento das fibras de $6 \mathrm{~mm}$, e teor de carbonato de 67 pcr. A análise térmica mostrou que os compósitos são estáveis até cerca de $300{ }^{\circ} \mathrm{C}$. Os resultados mostraram que os materiais obtidos possuem uma boa relação custo/benefício tornando promissora sua utilização.

Palavras-chave: Borracha nitrílica, carbonato de cálcio, fibra de sisal, compósitos.

\section{Properties of Nitrile Rubber, Sisal Fiber and Calcium Carbonate Hybrid Composites}

Abstract: In this work, nitrile rubber with sisal fibers composites and nitrile rubber with calcium carbonate and sisal fibers composites were developed. The influence from the calcium carbonate amount and size of sisal fibers on the composite properties was studied. The composites, with short fibers randomly distributed, were characterized by mechanical analysis, scanning electron microscopy (SEM), and thermogravimetric analysis (TGA). The optimal size of sisal fibers to reinforce the nitrile matrix was $6 \mathrm{~mm}$. The ideal volume of calcium carbonate was $67 \mathrm{phr}$. TGA analysis demonstrated that the composites are stable up to $300^{\circ} \mathrm{C}$. The materials developed have a good cost/benefits relation, being therefore promising their utilization.

Keywords: Nitrile rubber, calcium carbonate, sisal fiber, composite.

\section{Introdução}

As borrachas preparadas por copolimerização de butadieno e acrilonitrila são conhecidas por vários nomes genéricos, como Buna N, NBR ou Borracha Nitrílica; sendo este último o mais popularmente conhecido. O teor de acrilonitrila normalmente varia na faixa de 15 a $50 \%$, sendo que a propriedade mais significativa destas borrachas é sua excelente resistência a óleos e a solventes aromáticos, o que é controlado quase que exclusivamente pelo teor de acrilonitrila. Quanto mais alto esse teor, maior a resistência a óleos ${ }^{[1,2]}$. Adicionalmente elas exibem excelente resistência à abrasão e boas características de resistência à compressão. Devido a sua versatilidade, são usadas em aplicações que requerem resistência a combustíveis, ao aquecimento, à água, e permeabilidade a gases e como são de natureza polar isto lhes confere usos como adesivos ${ }^{[1,3]}$.

$\mathrm{O}$ carbonato de cálcio mineral é a mais importante e abundante de todas as rochas sedimentares empregadas comercialmente ${ }^{[4]}$. É o segundo tipo de carga branca mais usada em produtos de borracha, perdendo apenas para o caolim. A razão para esta popularidade é que altos teores podem ser usados junto às borrachas, com apenas pequena perda de maciez, elongação e resiliência ${ }^{[5]}$. Saad \& Younan ${ }^{[6]}$ estudaram uma combinação de carbonato de cálcio com fibras curtas de náilon 6 , como reforço para borracha natural e determinaram que o compósito com 25 pcr de fibras, associado a um teor de 40 pcr de carbonato foi o que apresentou as melhores propriedades mecânicas e elétricas.

Os polímeros nitrílicos são amorfos, e necessitam de cargas de reforço para que suas propriedades sejam otimizadas $^{[1]}$. O sistema borracha/reforço, no caso especial borracha/fibras, pode ser considerado um compósito que combina a resistência e rigidez das fibras curtas com o comportamento elástico da borracha ${ }^{[7]}$.

As fibras de sisal se destacam entre as fibras vegetais produzidas no Brasil, pelas suas características físicoquímicas e propriedades mecânicas. Esta fibra está entre as fibras vegetais mais utilizadas mundialmente ${ }^{[8]}$. Quimicamente, as fibras vegetais consistem de celulose, hemicelulose, lignina, pectina e uma pequena quantidade de ceras e gorduras ${ }^{[8]}$.

Autor para correspondência: Luiz H. C. Mattoso, Embrapa Instrumentação Agropecuária, Caixa Postal 741, CEP: 13560-970, São Carlos, SP. E-mail: mattoso@cnpdia.embrapa.br 
O objetivo deste trabalho foi realizar um estudo de compósitos de borracha nitrílica reforçados com fibra de sisal, na presença e ausência de carbonato de cálcio, buscando a obtenção de materiais com melhor desempenho e o entendimento da correlação estrutura e propriedades dos mesmos.

\section{Experimental}

\section{Materiais}

A borracha nitrílica utilizada foi a Nitriflex ${ }^{\circledR} \mathrm{N}-206$, produzida pela Nitriflex S.A., preparada com um teor de acrilonitrila de $45 \%$, com massa específica de $0,98 \mathrm{~g} / \mathrm{cm}^{3} \mathrm{e}$ viscosidade Mooney de 50 - 70 (ML 4' a $100^{\circ} \mathrm{C}$ ).

$\mathrm{O}$ carbonato de cálcio usado foi produzido pela empresa Beneficiadora de Minerais Curuçá Ltda, com massa específica de $2,50 \mathrm{~g} / \mathrm{cm}^{3}$, estrutura cristalina romboédrica e com $40 \%$ das partículas abaixo de $5 \mu \mathrm{m}$.

As fibras de sisal (variedade Agave sisalana), provenientes de Campina Grande/PB, foram extraídas de plantas no segundo ano de colheita, e possuíam 1,50 m de comprimento.

Utilizou-se como estabilizante o produto "Santowhite ${ }^{\circledR}$ crystals", produzido pela empresa Monsanto, e indicado pelo fabricante da borracha.

\section{Métodos}

Para o estudo da variação do teor de carbonato de cálcio sobre a borracha nitrílica foram avaliadas formulações com teores de carbonato iguais a $0,11,33,50,67,90,133$ e 200 pcr.

As fibras de sisal foram cortadas em uma guilhotina industrial manual marca Funtimod, com $70 \mathrm{~cm}$ de abertura. Para o processamento, as fibras foram alinhadas em um feixe e mantidas firmemente unidas através de uma fita adesiva em toda sua extensão. O feixe compactado tinha um aspecto cilíndrico com aproximadamente $5 \mathrm{~cm}$ de diâmetro. Ao ser guilhotinado obtinha-se "fatias", sendo a fita adesiva posteriormente removida e descartada. Com o objetivo de se verificar a eficiência da metodologia empregada para o corte das fibras, foi realizado o estudo da distribuição de comprimento usando uma lupa graduada Bausch \& Lomb, sendo analisados cerca de 300 fragmentos em cada amostra.

Para o estudo da influência do comprimento das fibras de sisal nas propriedades dos compósitos com a borracha nitrílica, as fibras utilizadas, nos comprimentos de 3,6,10 e $14 \mathrm{~mm}$, foram lavadas em água por $1 \mathrm{~h}$ a temperatura de $80 \pm 2{ }^{\circ} \mathrm{C}$, em seguida secas em estufas por $6 \mathrm{~h}$, à $80^{\circ} \mathrm{C}$. Foram realizados ensaios em compósitos borracha/sisal sem e com a adição de carbonato de cálcio nos teores de 33 e 67 pcr. O teor de fibra e de estabilizante foi mantido constante em 22 pcr e 1 pcr, respectivamente, para todos os estudos.

Os compósitos foram processados em uma calandra Mecanoplast modelo C-400-2S composta por moinho aberto de 2 rolos. Todas as amostras foram processadas à temperatura de $130 \pm 5^{\circ} \mathrm{C}$ e o tempo total para processamento foi estabelecido em 20 min: 5 min para mastigação da borracha, massa igual a $200 \mathrm{~g}$, e incorporação do estabilizante; $5 \mathrm{~min}$ para incorporação do carbonato de cálcio; 5 min para incorporação das fibras de sisal; e 5 min para homogeneização da massa. As amostras sem carbonato em sua composição tinham 5 min para adição deste componente incorporados ao tempo de mastigação da borracha; de forma que todas as amostras ficaram em processamento no moinho durante o intervalo de tempo de 20 min. A adição das fibras de sisal foi feita na última etapa para minimizar as quebras durante o processamento. Neste processamento não foi realizada a etapa de vulcanização da borracha.

Os ensaios de resistência à tração foram realizados em uma Máquina de Ensaio Universal - EMIC DL 500 MF, segundo a norma ASTM D 412-98, método A, com as seguintes condições: abertura entre garras de $50 \mathrm{~mm}$, velocidade de deslocamento das garras igual a $500 \mathrm{~mm} / \mathrm{min}$, célula de carga de 100 N. Foram ensaiados 5 corpos de prova para cada amostra.

As análises por termogravimetria (TG) foram realizadas em um equipamento NETZSCH modelo TG 209, com início à temperatura ambiente até $600{ }^{\circ} \mathrm{C}$, com uma razão de aquecimento de $10^{\circ} \mathrm{C} / \mathrm{min}$, usando nitrogênio como gás de arraste, com fluxo de $15 \mathrm{~mL} / \mathrm{min}$.

Para a caracterização através de microscopia eletrônica de varredura (MEV) utilizou-se um microscópio eletrônico marca ZEISS modelo DSM 960, com um feixe de elétrons de $20 \mathrm{kV}$. Sobre as amostras foi depositado uma camada de ouro "sputter coater" (plasma de argônio) marca BALZERS modelo SCD50.

\section{Resultados e Discussão}

A Figura 1 apresenta os resultados das propriedades mecânicas (módulo a 10\% de elongação, resistência à tração e elongação na ruptura), em função da adição de carbonato de cálcio à borracha nitrílica. Na faixa de composições estudadas, observa-se que a adição do carbonato, independentemente do teor, leva a um aumento no módulo e na elongação do material obtido quando comparado com a borracha pura, que é um resultado consistente com a literatura ${ }^{[9]}$. O máximo de elongação encontrado foi para o teor de 67 pcr de carbonato. Observa-se, também, que a adição gradativa de carbonato aumenta o valor de resistência à tração de ruptura, atingindo um máximo na formulação com 33 pcr; a partir do qual inicia-se um decaimento nesta propriedade. Este comportamento de reforço do carbonato, aumentando a resistência à tração de ruptura não é normalmente observado na literatura ${ }^{[9]}$, e estes resultados indicam que, provavelmente, existe uma adesão eficiente na interface borracha/carga, que pode ser proveniente da interação entre os grupos polares do carbonato com os da borracha, fazendo com que o carbonato sólido reforce a matriz nitrílica. A resistência à tração na ruptura passa por um máximo, e a partir deste valor o aumento de teor de carbonato leva a uma diminuição da resistência indicando que altos teores de carbonato influenciam na interação entre estas partículas e a matriz.

A partir destes resultados os demais estudos foram realizados com teores de 33 e 67 pcr de carbonato nas formulações. As curvas de TG para a borracha nitrílica pura e com 

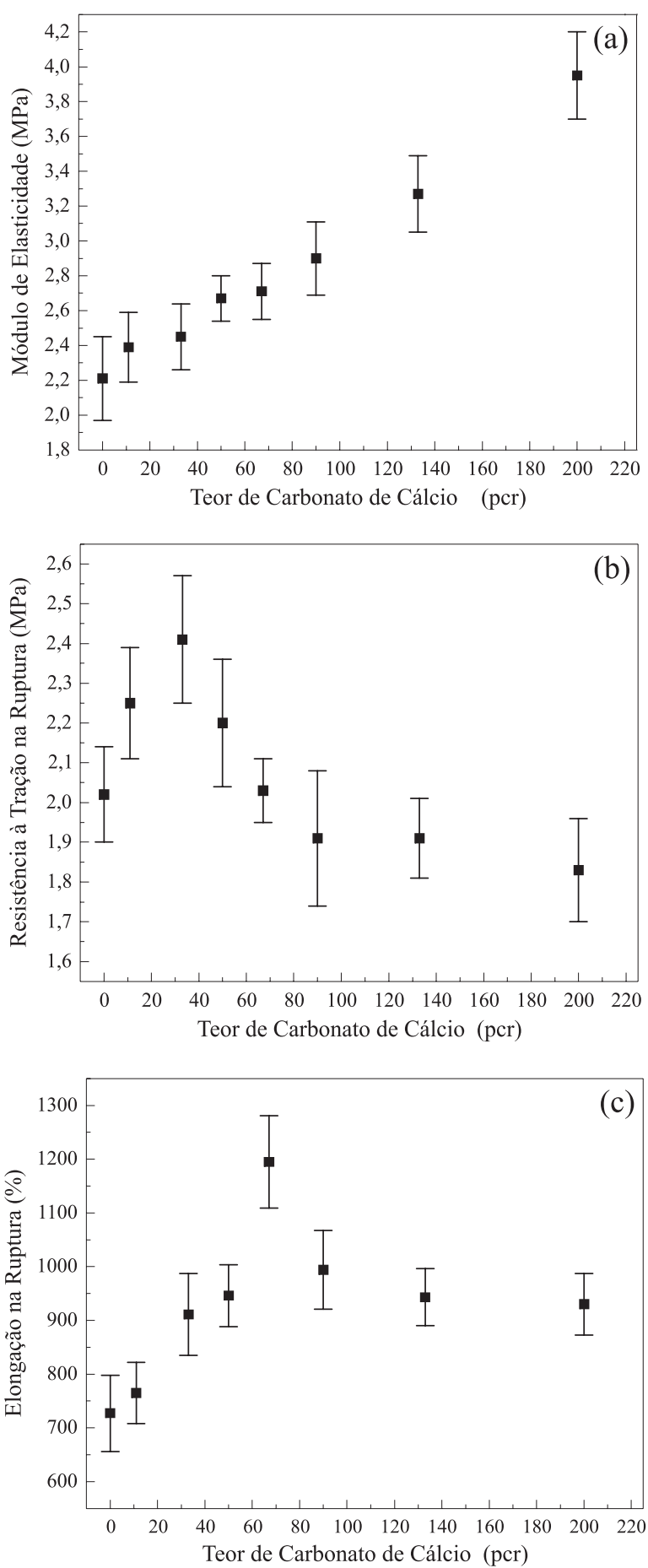

Figura 1. Curvas de módulo de elasticidade a 10\% de elongação (MPa), resistência à tração (MPa), e elongação na ruptura (\%), em função da variação de teor de carbonato de cálcio na borracha nitrílica.

a adição de 67 pcr de carbonato são apresentadas no gráfico da Figura 2, no qual observa-se que ocorre uma perda de massa de aproximadamente $2 \%$ até a temperatura de $220^{\circ} \mathrm{C}$ para os dois sistemas. Observa-se, também, que o perfil de decomposição térmica da borracha nitrílica não foi afetado pela incorporação do carbonato. Tanto a borracha nitrílica pura quanto a com carbonato apresentam boa estabilidade térmica até cerca de $340^{\circ} \mathrm{C}$ e a partir desta temperatura a perda de massa

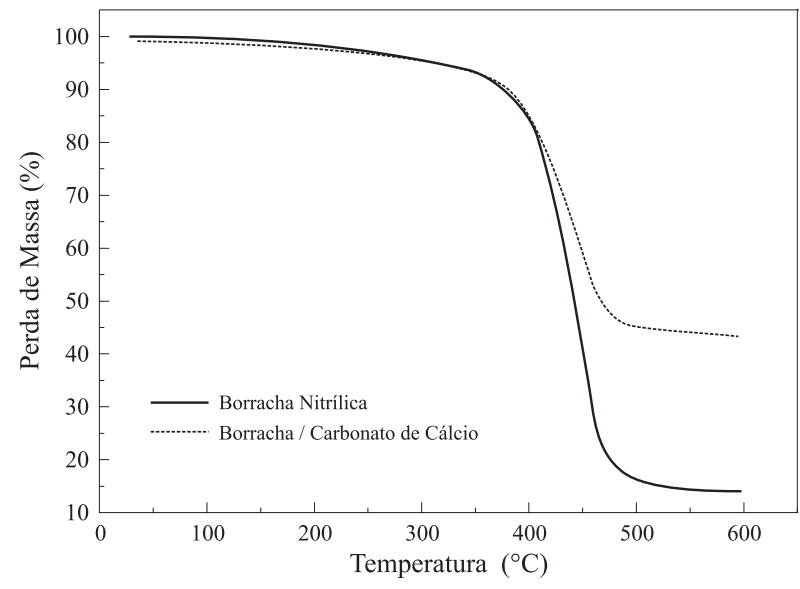

Figura 2. Curvas de TG para borracha nitrílica pura e a com 67 pcr de carbonato de cálcio. Razão de aquecimento de $10{ }^{\circ} \mathrm{C} / \mathrm{min}$, fluxo de $\mathrm{N}_{2}$ de $15 \mathrm{~mL} / \mathrm{min}$.

vai se acentuando e começa a ocorrer sua degradação estrutural, perdendo cerca de $50 \%$ de massa à temperatura de cerca de $440{ }^{\circ} \mathrm{C}$. Próximo a $480{ }^{\circ} \mathrm{C}$ a perda de massa passa a decair mais suavemente ocorrendo carbonização das amostras. À temperatura de $600{ }^{\circ} \mathrm{C}$, o resíduo é de aproximadamente $14 \%$ para a borracha pura e de cerca de $43 \%$ para a com carbonato, esta diferença no percentual de resíduo está relacionada ao teor de carbonato adicionado à matriz.

A Figura 3 apresenta uma micrografia obtida por MEV do carbonato de cálcio disperso na matriz de borracha, observa-se que a interface não apresenta trincas ou grandes falhas, ou seja, ocorre uma boa interação entre eles, o que indica que esta interação efetiva pode ser a responsável pelo fato de que para esta matriz o carbonato pode funcionar não apenas como uma carga de baixo custo para o compósito, como normalmente é mencionado na literatura ${ }^{[9]}$, mas também como uma carga de reforço, como mostrado pelo comportamento mecânico observado.

A Figura 4 apresenta uma micrografia representativa obtida por MEV da superfície longitudinal de uma fibra de sisal na forma em que é recebida, e nesta pode-se observar as células

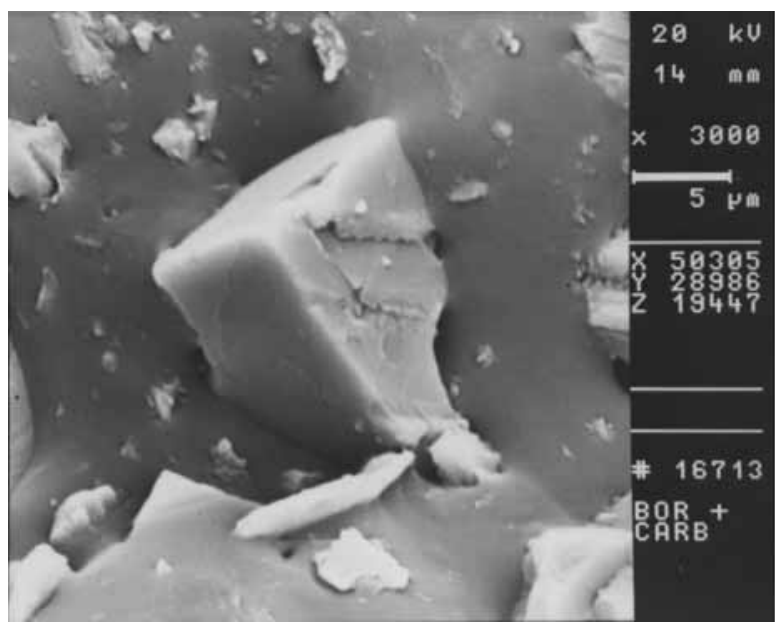

Figura 3. Micrografia obtida por MEV da superfície de fratura de um compósito de borracha nitrílica com carbonato de cálcio. Ampliação de $3.000 \mathrm{x}$. 


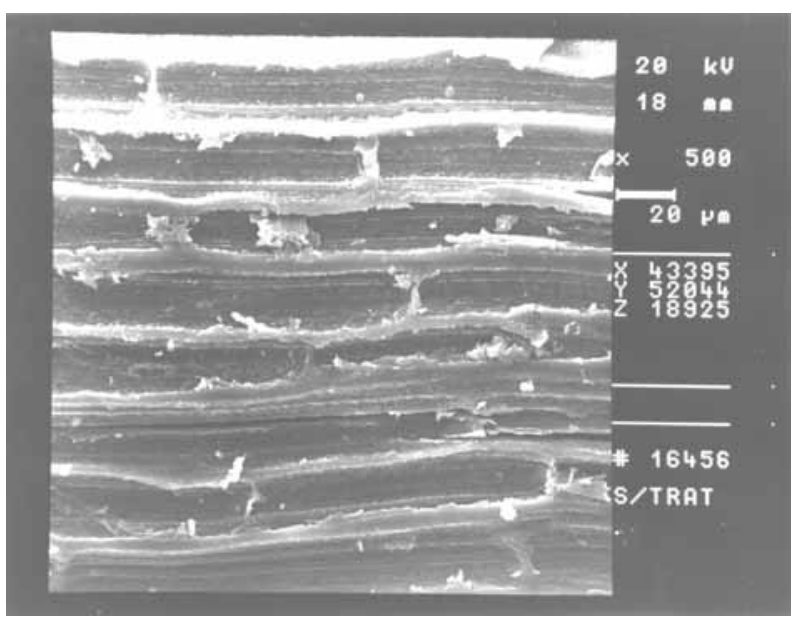

Figura 4. Micrografia obtida por MEV da superfície longitudinal da fibra de sisal sem tratamento. Ampliação de 500 x.

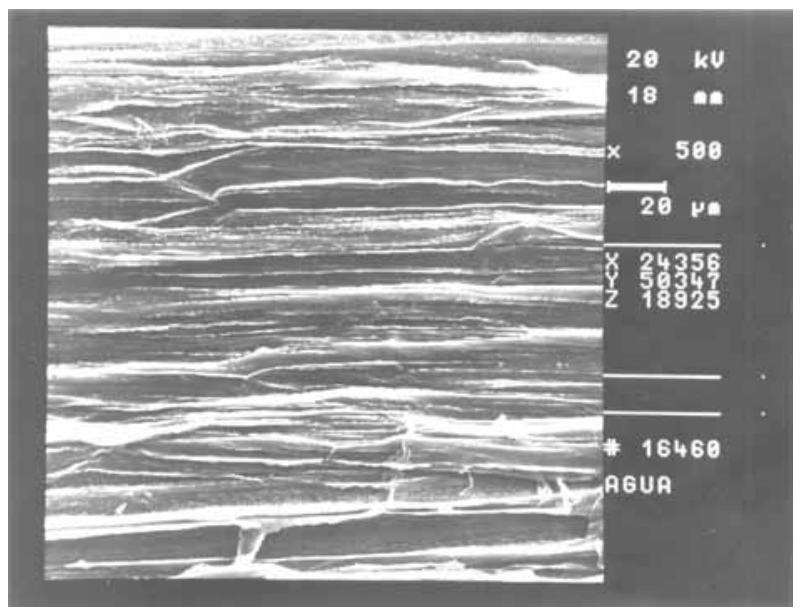

Figura 5. Micrografia obtida por MEV da superfície longitudinal de uma fibra de sisal lavada com água, durante $1 \mathrm{~h}$, a $80^{\circ} \mathrm{C}$. Ampliação de $500 \mathrm{x}$.

de parênquima envolvendo a fibra, bem como resíduos do processo de beneficiamento. Estudos realizados por Varghese e colaboradores $^{[10]}$ e por Joseph e colaboradores ${ }^{[11,12]}$ mostraram que os resíduos presentes na superfície das fibras vegetais diminuem a adesão quando estas fibras são utilizadas em materiais compósitos. Na Figura 5 é mostrada uma micrografia de uma fibra submetida ao processo de lavagem, e pode-se notar que a simples lavagem com água quente removeu grande parte dos resíduos provenientes do beneficiamento e também removeu parcialmente as células do parênquima. Kumar e Thomas ${ }^{[13]}$ observaram que a lavagem de fibras de sisal com água remove parcialmente impurezas da superfície das fibras, deixando-a mais rugosa, o que pode aumentar a adesão na interface fibra/matriz.

$\mathrm{O}$ resultado dos ensaios de distribuição de comprimento das fibras é apresentado na Figura 6, onde observa-se que através da metodologia utilizada para o corte das fibras obteve-se cerca de $80 \%$ destas nos comprimentos desejados, $3,6,10$ e $14 \mathrm{~mm}$. Os comprimentos das fibras utilizados foram escolhidos a partir de referências encontradas na literatura $^{[11,13,14]}$, nas quais a maioria dos compósitos estudados

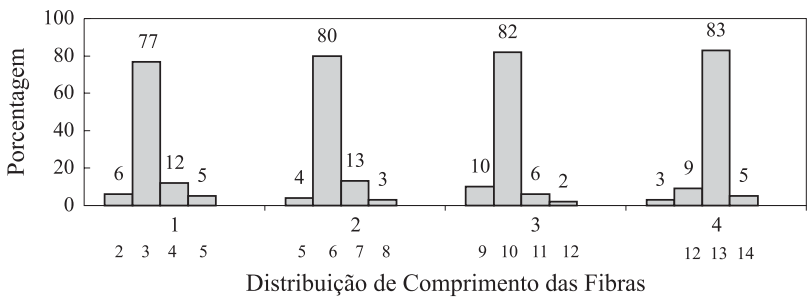

Figura 6. Distribuição percentual dos comprimentos das fibras de sisal

apresentou melhorias em suas propriedades quando as fibras de sisal foram empregadas em fragmentos compreendidos na faixa de 6 a $10 \mathrm{~mm}$.

Os resultados da influência da adição das fibras de sisal em diferentes comprimentos nas propriedades mecânicas dos compósitos com a borracha nitrílica com e sem carbonato de cálcio, são apresentados na Figura 7. Nas curvas referentes à resistência à tração e elongação na ruptura, observa-se que a adição das fibras levou a uma diminuição destas propriedades independentemente do comprimento de fibra empregado e da presença ou não do carbonato de cálcio em relação à borracha nitrílica. No entanto, percebe-se que para a resistência à tração, os compósitos com as fibras no comprimento de $6 \mathrm{~mm}$ são os que apresentam melhor desempenho com ou sem a presença de carbonato de cálcio. Estudos sobre o desempenho de materiais compósitos reforçados com fibras mostram que o comprimento crítico, ou a razão de aspecto crítica das fibras depende da fração volumétrica destas nos compósitos. Em baixa fração volumétrica, ou teor de fibras na matriz, as fibras influenciam pouco a resistência do compósito que é dominada pela matriz. Acima de uma fração crítica a resistência dos compósitos aumenta com o teor de fibras na matriz. Em geral, quanto maior a razão de aspecto menor é a fração volumétrica crítica ou teor critico ${ }^{[15,16]}$. A partir dos nossos resultados, observa-se que a o teor de 22 pcr de fibras de sisal é inferior à fração volumétrica critica a partir da qual as fibras passariam a agir como reforço no compósito, este teor é provavelmente ineficiente, de modo que as fibras agem como defeitos e fragilizam a matriz, reduzindo a resistência mecânica do compósito. Com relação ao módulo a 10\%, observa-se a adição das fibras levou a um aumento nesta propriedade em todos os casos e que o máximo valor de módulo ocorre para os compósitos com as fibras no comprimento de $6 \mathrm{~mm}$ e $67 \mathrm{pcr}$ de carbonato de cálcio. A partir deste comprimento da fibra ocorre decréscimo desta propriedade provavelmente devido à dificuldade de dispersão das fibras na matriz e à formação de interfaces fibra/fibra com pouca adesão. Observa-se também que a presença do carbonato de cálcio leva a um aumento significativo do módulo nos compósitos.

Uma micrografia representativa da superfície de fratura de um compósito com a fibra lavada é apresentada na Figura 8, pode-se observar a ocorrência de formação de junta adesiva entre a fibra e a matriz. No estudo realizado por MEV observa-se também que a presença do carbonato de cálcio não interferiu na adesão e homogeneidade dos compósitos estudados e que as fibras lavadas apresentaram boa compatibilidade com a matriz apresentando uma interface fibra/ma- 

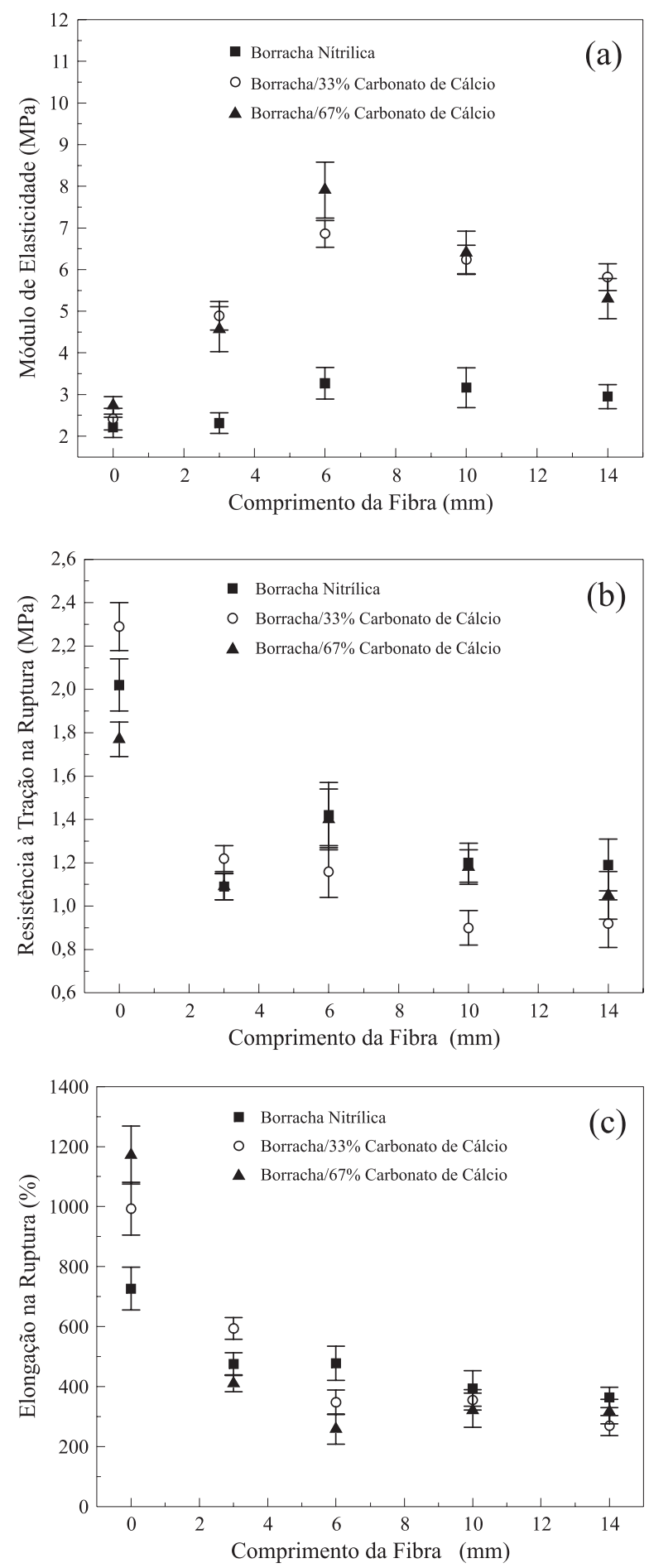

Figura 7. Curvas de módulo de elasticidade a $10 \%$ de elongação (MPa), resistência à tração (MPa) e elongação na ruptura (\%), para o estudo da variação do comprimento de fibra de sisal lavada em água quente, em compósitos com a borracha nitrílica; com a borracha nitrílica e 33 pcr de carbonato; e com a borracha nitrílica e 67 pcr de carbonato.

triz sem as falhas normalmente observadas na interface dos compósitos contendo as fibras sem tratamento.

\section{Conclusões}

Os estudos realizados mostraram que é possível a obtenção

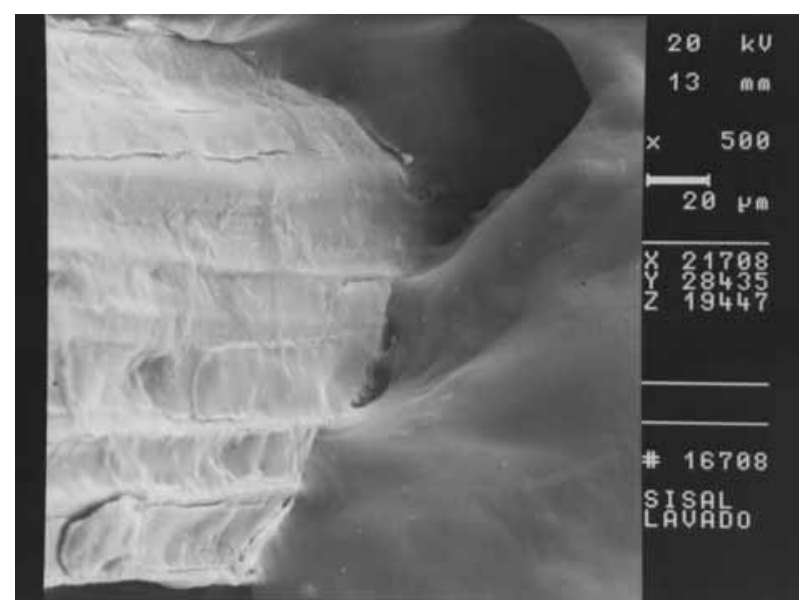

Figura 8. Micrografia obtida por MEV da superfície de fratura do compósito de borracha nitrílica com 22 per de fibras de sisal lavada. Ampliação de 500 x.

de compósitos borracha nitrílica/fibra de sisal pelo processamento por calandragem e que o tratamento de lavagem das fibras contribui para a eliminação de resíduos indesejáveis da superfície das fibras e para sua utilização em materiais compósitos. A presença da carga mineral em conjunto com as fibras de sisal funciona como carga de reforço, e não apenas como carga de enchimento, diminuindo o custo final do compósito. Dentro da faixa de estudos realizados, o teor de 67 pcr de carbonato de cálcio foi o que apresentou maiores contribuições para reforço dos compósitos. Para a matriz de borracha nitrílica, associada ou não ao carbonato de cálcio, concluiu-se que nas condições experimentais empregadas o sisal comportou-se como uma carga de reforço aumentado o módulo de elasticidade do material obtido. O comprimento das fibras de sisal para otimização das propriedades mecânicas dos compósitos foi de $6 \mathrm{~mm}$.

\section{Agradecimentos}

O autores agradecem à Embrapa/CNPA pelo fornecimento das fibras de sisal, ao Dr. Fábio C. Ferreira (Unesp/Presidente Prudente) pelas análises térmicas, e ao CNPq e à Fapesp pelo apoio financeiro.

\section{Referências Bibliográficas}

1. Winspear, G. G., - The Vanderbilt Rubber Handbook, Norwalk, p.99-118, (1968).

2. Jerrams, S. J., Kaya, M., Soon, K. F. - Mater. Design, 19, p.157-167, (1998).

3. Miles, D. C., Briston, J. H. - Tecnologia dos Polímeros, São Paulo, p.359-400 e 523-526, (1975).

4. Patton, T. C. - Pigment Handbook - Properties and Economics, New Jersey, p.109-128, (1972).

5. Krysztafkiewicz, A. - Powder Technology, 63, p.1-11, (1990). 
6. Saad, A. L. G., Younan, A. F. - Polym. Degrad. and Stabil., 50, p.133-140, (1995).

7. Martins, M. A., Mattoso, L. H. C. - J. Appl. Polym. Sci., 91, p.670-677, (2004).

8. Martins, M. A., Joekes, I. - J. Appl. Polym. Sci., 89, p.25072515, (2003).

9. Askeland, D. R. - The Science and Engineering of Materials, Boston , p.527-572, (1994).

10. Varghese, S., Kuriakose, B., Thomas, S., Koshy, A. T. J. Adhes. Technol., 8, p.235-248, (1994).

11. Joseph, K., Thomas, S., Pavithran, C. - Polymer, 37, p.5139-5149, (1996).
12. Joseph, K., Thomas, S. - J. Reinf. Plast Compos., 12, p.139-155, (1993).

13. Kumar, R. P., Thomas, S. - Polym. International, 38, p.173-182, (1995).

14. Geethamma, V. G., Joseph, R., Thomas, S. - J. Appl. Polym. Sci., 55, p.583-594, (1995).

15. Mallick. P. K. - Fiber-Reinforced Composites, Marcel Dekker, Inc., New York, (1988).

16. Joseph, K., Medeiros, E. S., Carvalho, L. H. - Polímeros: Ciência e Tecnologia, 9, p.136-141, (1999).

Enviado: 02/12/03

Reenviado: 23/03/04

Aprovado: 25/03/04 